\title{
The utilization of diets containing acetate salts by growing lambs as measured by comparative slaughter and respiration calorimetry, together with rumen fermentation
}

\author{
By F. D. DeB. HOVELL, J. F. D. GREENHALGH and F. W. WAINMAN \\ The Rowett Research Institute, Bucksburn, Aberdeen $A B 2{ }_{9} S B$
}

(Received 12 September 1975-Accepted Io October 1975)

\begin{abstract}
I. In a comparative slaughter experiment, growing lambs were given concentrate diets in which 14 or $19 \%$ metabolizable energy (ME) provided by barley was replaced by sodium, calcium and potassium salts of acetic acid. As the proportion of $M E$ as acetate was increased, energy retention decreased. $M E$ intake was $927 \mathrm{I}, 9430$ and $9217 \pm 67 \mathrm{~kJ} / \mathrm{d}$ and energy retention was 2698,2422 and $2280 \pm 71 \mathrm{~kJ} / \mathrm{d}$ for the diets containing 0 , 14 or $19 \% \mathrm{ME}$ as acetate respectively. There were no differences in protein deposition. The efficiency of utilization of acetate for energy retention $\left(k_{f}\right)$ was calculated by difference to be 3 and $10 \pm 13 \%$ respectively for the diets containing 14 and I9\% ME as acetate.

2. In a second experiment, growing lambs were given concentrate diets in which 4 or $16 \%$ ME provided by barley was replaced by salts of acetic acid, and utilization was measured by indirect calorimetry. There were no significant differences in the utilization of the diets for maintenance $\left(k_{m}\right)$ or energy retention $\left(k_{f}\right)$. The $k_{m}$ values were $82 \cdot 4 \pm 2 \cdot 3$ and $81 \cdot 2 \pm 0 \cdot 7 \%$, and $k_{f}$ values were $67.4 \pm 4.5$ and $65.8 \pm 2.7 \%$ respectively for the diets providing 4 and $\mathrm{I} 6 \% \mathrm{ME}$ as acetate. The $k_{f}$ of the additional acetate in the diet providing $16 \% \mathrm{ME}$ as acetate was calculated by difference to be $54 \%$.

3. The acetate and $\mathrm{Ca}$ concentrations of the rumen digesta were increased by including acetate salts in the diet, but $\mathrm{Na}$ and $\mathrm{K}$ concentrations were not affected.

4. It is concluded that the best explanation for the poor utilization of acetate in the comparative slaughter experiment is that acetate was poorly utilized for lipogenesis. The calorimetry experiment contained relatively large errors, but the results suggest that acetate may be utilized efficiently in some circumstances. It is suggested that these results and apparently conflicting results in the literature may be explained by the concept that the efficient utilization of acetate is dependent upon the supply of glucose or glucose precursor.
\end{abstract}

The efficiency with which acetic, propionic and $n$-butyric acids are utilized by ruminants in positive energy balance was first reported by Armstrong \& Blaxter (1957), who measured the heat increments resulting from the infusion of dilute solutions of the acids into the rumens of sheep confined in respiration chambers. Additional energy retention was promoted with an efficiency of $33 \%$ by acetic acid, $56 \%$ by propionic acid and $62 \%$ by butyric acid. When two mixtures of the three acids containing 59 or $14 \%$ energy as acetic acid were infused, they were utilized with an efficiency of 32 and $58 \%$ respectively (Armstrong, Blaxter, Graham \& Wainman, 1958). These findings provided a very satisfactory explanation of the fact that the metabolizable energy (ME) of diets which promote a high-acetate fermentation is less efficiently utilized by fattening ruminants than is that from diets which promote a high-propionate fermentation (Blaxter \& Wainman, I964).

In subsequent experiments in which an assessment of growth has been the main criterion, no difference could be found between the three acids when these were given by infusion (Rook, Balch, Campling \& Fisher, I963), or as sodium and calcium salts mixed into the diet (Ørskov \& Allen, 1966a, b, $c$; Ørskov, Hovell \& Allen, I966), 
although Ørskov \& Allen (I966c) and Poole \& Allen (1970) found that acetate, when included in a high-concentrate diet, was more efficiently utilized than when included in a low-concentrate diet. In a comparative slaughter experiment, Bull, Reid \& Johnson (1970) supplemented diets of hay alone or hay and maize with triacetin and were unable to find differences in utilization by sheep of the two basal diets, or of the supplemented and unsupplemented diets.

In the experiments reported here, salts of acetic acid were substituted for the fermentable carbohydrate of a concentrate diet given to growing lambs.

\section{EXPERIMENTAL}

In Expt I utilization of diets containing salts of acetic acid was measured by comparative slaughter. A preliminary report of this work has already been given (Hovell \& Greenhalgh, 1970). In Expt 2 utilization of diets containing salts of acetic acid was measured by indirect calorimetry. In Expt 3 rumen volatile fatty acids (VFA) and cation concentrations were measured in sheep given the diets used in Expt $\mathrm{I}$.

\section{Animals}

Expt I. Twenty-nine male Suffolk $\times$ Greyface lambs were weaned in May I 968 at weights between 8 and $\mathrm{r} 3 \mathrm{~kg}$. They were given a diet based on rolled barley and extracted soya-bean meal, and they were treated with an anthelmintic ('Nilverm', based on levamisole; ICI Pharmaceuticals, Alderley Park, Macclesfield, Cheshire). No measurements of worm burden were made. At an age of about io weeks, five animals were allocated to an 'initial-slaughter' group and were killed at weights between 18 and $23 \mathrm{~kg}$, and the remaining twenty-four animals were started on experiment at weights between 18 and $20 \mathrm{~kg}$.

Expt 2. Four Suffolk $\times$ Romney wether lambs, weighing initially $35-40 \mathrm{~kg}$ and aged about 6 months, were accustomed to metabolism crates and then to a respiration chamber. When selected for tests they were treated with an anthelmintic as described previously.

Expt 3. Rumen samples were provided by three 2-year-old Suffolk $\times$ Greyface wether sheep which had been fitted with permanent rumen cannulas.

\section{Treatment and design}

Expt I. The lambs were given one of three diets, o, I4 or $19 \% \mathrm{ME}$ as acetate (control, acetate-I4 and acetate-I9 respectively), at one of two levels (753 or $837 \mathrm{~kJ}$ assumed $\mathrm{ME} / \mathrm{kg}^{0.73}$ per d) and slaughtered at one of two weights (40 or $45 \mathrm{~kg}$ ). The experiment was thus of $3 \times 2 \times 2$ factorial design and it was replicated.

Expt 2. The lambs were given each of two diets (4 or I6\% ME as acetate (control and acetate respectively)) at each of two levels ( 335 and $670 \mathrm{~kJ}$ assumed $\mathrm{ME} / \mathrm{kg}^{0 \cdot 75}$ per d), according to a $4 \times 4$ Latin-square design, for periods of 4 weeks. The design was such that the two periods on each diet and at each feeding level were contiguous (e.g. control-low, control-high, acetate-high, acetate-low). The lambs were fasted at the beginning and end of the experiment. 
Table I. Composition of experimental diets given to lambs

\begin{tabular}{|c|c|c|c|c|c|}
\hline \multirow{3}{*}{$\begin{array}{c}\cdots \\
\text { Constituents }(\mathrm{g} \text { DM/kg DM) }\end{array}$} & \multicolumn{3}{|c|}{ Expts $I$ and 3} & \multicolumn{2}{|c|}{ Expt 2} \\
\hline & Control & Acetate-I4 & Acetate-19 & Control & Acetate \\
\hline & \multicolumn{5}{|c|}{ Constituents (g DM/kg DM) } \\
\hline Barley* & 782 & 613 & $53 \circ$ & 727 & 501 \\
\hline Extracted soya-bean meal & I49 & 166 & 176 & $14 \mathrm{I}$ & I 65 \\
\hline White fish meal & 37 & 42 & 44 & 35 & $4 \mathrm{I}$ \\
\hline Chopped barley straw & - & - & - & $5^{\circ}$ & 40 \\
\hline Sodium acetate & - & 79 & I 19 & - & 109 \\
\hline Calcium acetate & - & $6 x$ & $9 \mathrm{I}$ & - & 83 \\
\hline Potassium acetate & 一 & II & I7 & - & I5 \\
\hline Calcined magnesite & $I$ & $\mathbf{r}$ & $\mathbf{I}$ & $\mathbf{I}$ & $\mathbf{I}$ \\
\hline Steamed bone-flour & 20 & 12 & 一 & - & - \\
\hline Sodium orthophosphate & - & 7 & I 5 & $一$ & - \\
\hline Sodium chloride & 5 & 2 & 2 & 5 & 5 \\
\hline Adisco $†$ & 6 & 6 & 6 & 6 & 6 \\
\hline Molasses & - & - & - & I0 & 6 \\
\hline Dicalcium phosphate & - & - & - & I4 & 14 \\
\hline Limestone & - & 一 & - & 8 & - \\
\hline \multicolumn{6}{|l|}{ Composition (/kg DM) } \\
\hline Crude protein (nitrogen $\times 6.25)(\mathrm{g})$ & 194 & 185 & I 82 & I 94 & 189 \\
\hline Organic matter $(\mathrm{g})$ & 942 & 867 & 832 & 916 & 844 \\
\hline Gross energy (MJ) & 18.68 & $17 \cdot 84$ & I $7 \cdot 20$ & $18 \cdot 16$ & 17.54 \\
\hline Acetate energy (MJ) & $\circ$ & $x \cdot 67$ & $2 \cdot 16$ & 0.39 & $\mathbf{I} \cdot 79$ \\
\hline Assumed MEf (MJ) & $12 \cdot 22$ & I I 84 & $11 \cdot 72$ & I I 86 & I I 55 \\
\hline Corrected ME $\S(\mathrm{MJ})$ & $11 \cdot 50$ & II 67 & II I 7 & II $\cdot$ I 3 & II I IO \\
\hline Acetate energy ( $\%$ corrected ME) & $\circ$ & 14.3 & 19.3 & $3 \cdot 6$ & I5.7 \\
\hline $\mathrm{Na}(\mathrm{g}) \|$ & 3 & 30 & $5 \mathrm{I}$ & 6 & 35 \\
\hline$K(g) \|$ & 7 & I I & 13 & 8 & 12 \\
\hline $\mathrm{Ca}(\mathrm{g}) \|$ & IO & 22 & 27 & I I & 30 \\
\hline Phosphorus (g) $\|$ & 8 & 8 & 8 & 8 & 8 \\
\hline
\end{tabular}

All diets contained in addition ( $/ \mathrm{kg} \mathrm{DM}): \mathrm{ZnCO}_{3} \cdot 2 \mathrm{ZnO} \cdot{ }_{3} \mathrm{H}_{2} \mathrm{O} 50 \mathrm{mg}, \mathrm{MnSO}_{4} \cdot{ }_{4} \mathrm{H}_{2} \mathrm{O}$ I20 mg, $\mathrm{FeSO}_{4} \cdot 7 \mathrm{H}_{2} \mathrm{O}$ I0O mg, $\mathrm{CoSO}_{4} \cdot 7 \mathrm{H}_{2} \mathrm{O}_{2} \mathrm{mg}, \mathrm{KIO}_{3} 0.2 \mathrm{mg}$.

DM, dry matter; ME, metabolizable energy.

* Rolled in Expt r, ground in Expt 2.

$\uparrow$ Proprietary supplement containing (/g): $300 \mu \mathrm{g}$ retinol equivalent (as retinyl palmitate), $5 \mu \mathrm{g}$ cholecalciferol.

† Calculated as (MJ/kg DM): barley $12 \cdot 93$, soya-bean meal II.55, fish meal $9 \cdot 96$, molasses $\mathrm{II} \cdot 97$, barley straw $7 \cdot 36$; acetate $874 \mathrm{~kJ} / \mathrm{mol}$ acetic acid.

$\S$ See Tables 3 and 7 for details of correction.

|| Calculated from reported values of constituents (Evans, I960), and chemical composition of salts.

Expt 3. The cannulated sheep each received each of the diets used in Expt I for a period of 4 weeks according to a $3 \times 3$ Latin-square design.

\section{Diets}

Expts $\mathrm{I}$ and 3 . The composition of the diets used is given in Table $\mathrm{I}$. The acetates were added as their anhydrous salts, and were assumed to have a ME value equal to the heat of combustion of their acid equivalent $(874 \mathrm{~kJ} / \mathrm{mol}$ acid$)$. The crude protein (nitrogen $\times 6.25$ ): assumed ME ratio was kept constant by adjusting the proportionality of soya-bean meal-fish meal $(80: 20 \mathrm{w} / \mathrm{w})$ with barley. All the diets were pelleted; the control and acetate-I 4 diets were extruded through a $9.5 \mathrm{~mm}$ die. Considerable difficulties were experienced in pelleting the acetate-1 9 diet, which was eventually 


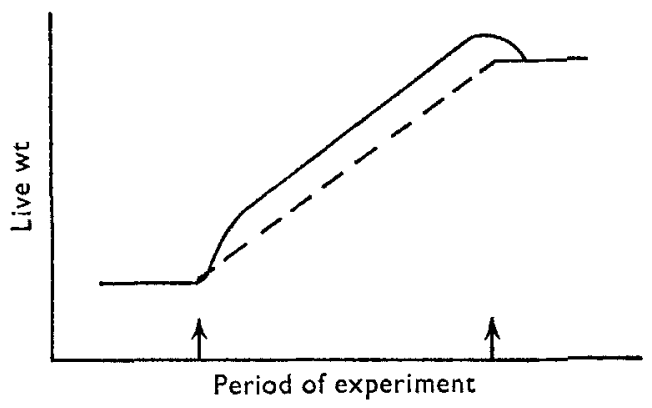

Fig. I. Expt 2. Diagrammatic representation of the correction of live weight of the lambs for differences in gut fill when they were given the diets containing 4 (control) or I6 (acetate) \% metabolizable energy (ME) as acetate at two levels $\left(670\right.$ and $335 \mathrm{~kJ}$ assumed $\mathrm{ME} / \mathrm{kg}^{0 \cdot 75}$ per d). $\uparrow$, The level of feeding was changed; $(-)$, determined live weight; (- - ), corrected live weight.

extruded through a special short-bore mineral die $\left(\mathrm{r}_{3} \mathrm{~mm}\right)$. This diet was intended to contain 2I \% ME as acetate, but some acetate was lost by repeated handling. The actual acetate levels given were determined by Markham distillation (see p. 348). Two values for ME are given: (I) assumed ME, which was calculated from assumed values for the constituents, and (2) corrected ME, which was calculated from the measured digestibility of the diets multiplied by a factor derived from Expt 2 to give ME corrected for heat of fermentation.

Expt 2. The composition of the diets is given in Table I. The diets were prepared as in Expt $\mathrm{I}$ except that all diets were pelleted $(9.5 \mathrm{~mm}$ die) complete with minerals and vitamins, but the barley straw was excluded and given separately, and ground barley was used instead of the rolled barley as in Expt I. Considerable difficulties were again experienced in pelleting the acetate diet, and the diets which should have contained o and $20 \%$ ME as acetate were found on analysis to contain 3.6 or $15.7 \%$ ME as acetate. This was probably because the acetate diet was processed first and some salts remained in the machinery. In this experiment corrected ME was calculated by deducting from the determined ME an amount of energy equal to $80 \%$ of the heat of combustion of the evolved methane (Blaxter, $1967 a$ ). The pellets were thoroughly mixed before the experiment began.

\section{Management}

Expt I. All animals were housed indoors in individual pens with concrete floors and bedded on sawdust. They were fed at 08.30 and 16.30 hours, water was always available, and they were weighed three times weekly before the morning meal. All animals were individually rationed and levels were adjusted weekly to live weights, which were estimated from individual cumulative growth curves. Any food not eaten, a situation which did not occur regulariy after the ist week of the experiment, was returned to the lambs and eaten during subsequent weeks.

Expt 2. The animals were housed in individual stalls with slatted floors which were of similar dimensions to the cage used in the chamber. They were given their daily ration as two equal meals at 08.30 and 16.30 hours (09.30 and 17.00 hours when in the chamber). Water was available at all times, and the animals were weighed three 
times weekly before their morning meal. Since the animals grew from about $40 \mathrm{~kg}$ to nearly $60 \mathrm{~kg}$ while on experiment, and there were differences in gut fill between the two feeding levels, the live weights were plotted as a cumulative growth curve and the values used for subsequent calculations were estimated by eye from the curve corrected for fill as shown in Fig. I. Food intakes were kept constant after the roth day of each period, any small adjustments at this time being based on weight changes during the first ro $\mathrm{d}$ of the period.

Expt 3. The cannulated sheep were individually penned, were bedded on sawdust and were offered $16.7 \mathrm{MJ}$ assumed $\mathrm{ME} / \mathrm{d}$, which was equivalent to about $753 \mathrm{~kJ} /$ $\mathrm{kg}^{0.75}$ per $\mathrm{d}$. They were fed at 08.30 and $\mathrm{I} 6.30$ hours.

\section{Health}

No problems attributable to the experimental treatments were encountered.

\section{Experimental techniques}

Digestibility of diets. In Expt $\mathrm{I}$ the digestibility of the diet was measured using the animals of one replicate, towards the end of the experiment. The pens were cleared of sawdust 2 weeks before a Io $\mathrm{d}$ total faeces collection was made. Faeces were stored at $\mathrm{I}^{\circ}$ until the collection was complete. In Expt 2 faeces were collected during the $3 \mathrm{~d}$ each animal was in the chamber and for the next $4 \mathrm{~d}$, and were stored at $-10^{\circ}$.

Slaughter and processing $(E x p t \mathrm{I})$. The 'initial-slaughter' group was killed at the Institute, and the rest of the animals at a commercial abattoir. Killing was by captivebolt gun, and the throat was then cut for bleeding. All components were weighed immediately or sealed into polyethylene bags and weighed on return to the Institute. The head was severed from the neck at the anterior face of the atlas vertebra. The feet were severed from the carcass at the proximal end of the metacarpals-tarsals. The carcass was split down the centre of the spinal column, the right side being retained for chemical analysis. The animals were processed and analysed as four components: $(a)$ right half of the carcass, $(b)$ skin, $(c)$ wool, $(d)$ all the remaining components (the non-carcass remainder). The skin and wool were separated by keeping the pelt at room temperature for 2 or $3 \mathrm{~d}$, after which time the wool could easily be pulled away from the skin.

The half-carcass, non-carcass remainder and skin were minced twice using a Wolfking B 200 LF mincer (St Lawrence Mink Farm Supply Ltd, Wolfcastle, Dyfed, Wales) with a $5 \mathrm{~mm}$ end-plate, mixed in a bakery-type mixer (Baker-Perkins Engineering, Peterborough), sampled into open aluminium-foil trays, and stored at $-20^{\circ}$ until analysed. The wool was chopped using the mincer with a $13 \mathrm{~mm}$ end-plate, mixed, and stored in a sealed polyethylene bag at $\mathrm{I}^{\circ}$. The composition of the halfcarcass was assumed to be representative of the whole carcass.

Calorimetry (Expt 2). The chamber used was one of the Institute sheep chambers (Wainman \& Blaxter, 1969). Urine was continuously evacuated through a funnel strapped under the animal (Wainman \& Paterson, r 963). Sulphuric acid was used as a preservative, sufficient being added to neutralize the considerable quantities of 
carbonate excreted in the urine when the lambs were given the acetate diet. Heat production was calculated from oxygen consumption, carbon dioxide and methane production, and urinary $\mathrm{N}$ using the equation of Brouwer (1965). When the lambs were given the acetate diet, calcium carbonate was excreted in the faeces, therefore the $\mathrm{CO}_{2}$ excreted by this process was estimated and included in the final calculation of heat production, although the correction made never exceeded $\mathrm{I} \%$ of total heat production. A correction was applied for the metabolism of acetate present in the diets, as Brouwer's ( 1965 ) equation over-estimated (by $75 \mathrm{~kJ} / \mathrm{mol}$ acetate) the heat evolved from the oxidation of acetate. It was assumed that the amount of acetate oxidized was in direct proportion to its contribution to ME.

The initial plan was to place the animals in the chamber for the $4^{\text {th }}$ week of each period and to measure gaseous exchange over the last $5 \mathrm{~d}$. However, it was found that the animals frequently refused food from about the $3^{\text {rd }}$ or $4^{\text {th }}$ day in the chamber. The problem was solved by placing the animals in the chamber for two periods of $3 \mathrm{~d}$ separated by $4 \mathrm{~d}$ in their stalls. Values for each $3 \mathrm{~d}$ period for gaseous exchange and urine excretion were analysed separately; thus two measurements (period I and period 2) for each diet at each level were made with each animal. Of the thirty-two measurements possible, twenty-nine were completed, although on two occasions a third period was necessary to secure two satisfactory measurements.

Rumen sampling (Expt 3). The rumens of the cannulated animals were sampled on the 26 th and 28 th days of the $28 \mathrm{~d}$ periods six times during the day $(08.00,09.30$, I I. 30 , $\mathrm{I} 3.30, \mathrm{I} 5.30$ and $\mathrm{I} 7.30$ hours). The $\mathrm{pH}$ of each sample was taken immediately and the sample was then poisoned with mercuric chloride and stored at $-20^{\circ}$. Equal amounts of the day-26 and day-28 samples were bulked for each sampling time, giving six samples/sheep per period, for chemical analysis.

\section{Chemical analysis}

Faecal and tissue samples were freeze-dried before analysis, apart from the faecal samples analysed for $\mathrm{N}$ and $\mathrm{CO}_{2}$. Urine energy was determined on freeze-dried material, the urine being dried in a dish lined with polyethylene, and polyethylene and urine being burnt together in the bomb calorimeter. Rumen digesta were prepared for VFA analysis by centrifugation. $\mathrm{N}$ was determined by the automated Kjeldahl method of Davidson, Mathieson \& Boyne (1970); fat as diethyl ether extract (Association of Official Agricultural Chemists, 1965); Ca by the automated method of Gitelman (1967); Na and potassium by flame photometry, the samples being ashed at $450^{\circ}$ and taken up in concentrated hydrochloric acid; total VFA by steam distillation in a Markham still and titration against $O \cdot I$ M-sodium hydroxide using phenol red as the indicator; individual VFA by gas-liquid chromatography (Pye Unicam Ltd, Cambridge; with a Pye IO4 ionization detector); and energy using an adiabatic bomb calorimeter (A. Gallenkamp \& Co. Ltd, London $\mathrm{EC}_{2} \mathrm{P}$ 2ER), corrections were made for carbon only. Ash in tissue samples was determined by ashing at $600^{\circ}$, but for samples of diet and faeces the modification of Hovell \& Ørskov (1972) was used which corrects for carbonate converted into oxide by the ashing process. Wool fibre was washed in hot water and detergent, dried and extracted with diethyl ether. Urine 
samples were checked for ketones with Labstix (Ames Chemical Co. Ltd, Stoke Poges, Slough, Bucks.). Carbonate was determined in the faeces from Expt 2 by manometric measurement of the $\mathrm{CO}_{2}$ evolved when the faeces were boiled with excess $\mathrm{HCl}$ (Hovell, 1972).

\section{Statistical analysis}

Expt I was analysed as a replicated $3 \times 2 \times 2$ factorial design. The interactions were always non-significant and they were included in the estimate of residual variation when standard errors were calculated. Expt 2 was analysed as two (period $I$ and period 2) $4 \times 4$ Latin squares. Residual variation was that remaining after removal of variation attributable to period (squared), animal, diet, period and the square of the period $\times$ animal, diet and period interactions. Expt 3 was analysed as a $3 \times 3$ Latin square on the mean value of the six samples taken.

\section{RESULTS}

\section{Digestibility and $\mathrm{ME}$ content of diets}

Expt I. The digestibility values are given in Table 2. The basal coefficients were calculated on the assumption that the energy and organic matter of the salts were completely digestible. The 'observed' digestibility of the acetate-I9 diet was slightly lower than the predicted value, which suggests either that acetate given at high levels was not completely digested, or (and this is the more likely alternative) that the digestibility of the basal constituents was slightly reduced.

Expt 2. At the high level of feeding there was again a suggestion that the digestibility of the basal constituents was slightly reduced by acetate. This was not statistically significant for energy, but was significant $(P<0.01)$ for $\mathrm{N}$. The agreement between period $\mathrm{I}$ and period 2 was very good ( 0.843 and $0.848 \pm 0.0045$ respectively, for energy).

\section{Utilization of the diets}

\section{Expt I. Comparative slaughter}

Effect of feeding level and slaughter weight. Slaughter weight had no significant effect when the results were expressed as rates of gain of body or body component. The only statistically significant effects of level of feeding were on the rates of gain (mean $\pm \mathrm{SE}$ of difference for the 753 and $837 \mathrm{~kJ} / \mathrm{kg}^{0.73}$ per d levels respectively) of the non-carcass remainder ( 40 and $44 \pm \mathrm{r} \cdot 6 \mathrm{~g} / \mathrm{d} ; P<0.05$ ), whole-body fat $(40.3$ and $49.7 \pm \mathrm{I} \cdot 9 \mathrm{~g} / \mathrm{d}$; $P<0.001$ ) and whole-body energy (2293 and $2644 \pm 84 \mathrm{~kJ} / \mathrm{d} ; P<0.01$ ). Protein gains (excluding wool) were the same $(25 \cdot 2 \mathrm{~g} / \mathrm{d})$. None of the interactions with diet was significant and therefore the results are given as the mean of all the values for each diet.

Effect of diet. The final weights of lambs and their body components, their estimated initial weights, daily food intakes and period on experiment, are given in Table 3 . The small but significant differences in assumed $M E$ intake disappeared when these were expressed as corrected ME. There were no differences between dietary treatments in period on experiment, final empty-body-weight or hot-carcass weight. There was a progressive and significant decrease in the weight of the non-carcass remainder as the 


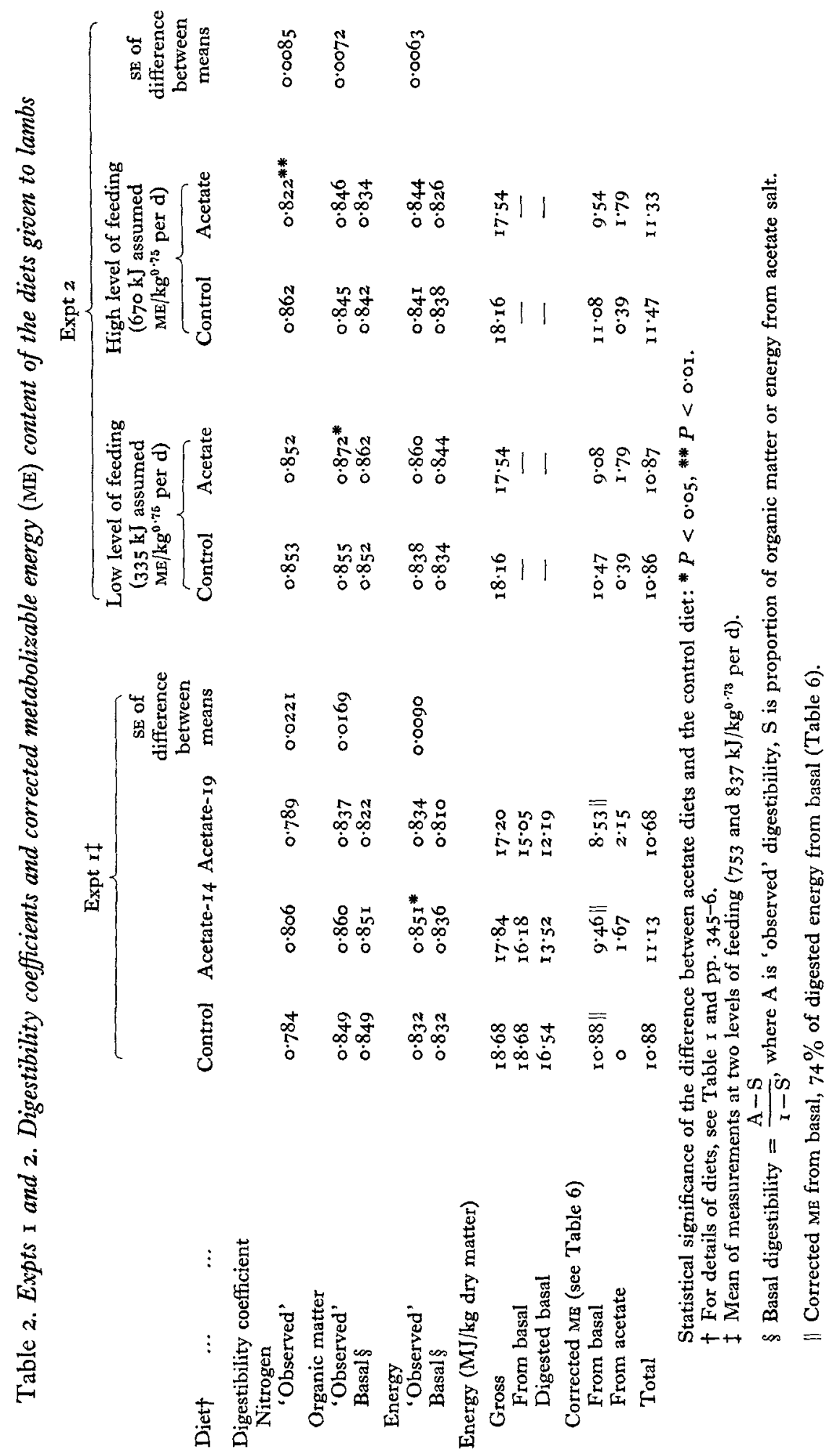


Table 3. Expt I. Effect of diets containing 14 (acetate-14) or 19 (acetate-19) \% of their metabolizable energy (ME) as acetate on the weight of male lambs initially 10 weeks old, and of their body components

\begin{tabular}{|c|c|c|c|c|c|}
\hline & & & Diet & & \\
\hline & $w t \dagger$ & Control & Acetate-I4 & Acetate- $I 9 \S$ & treatments $(n 8)$ \\
\hline Period on experiment (d) & & 120 & 123 & 122 & 5 \\
\hline $\begin{array}{l}\text { ME }(\mathrm{kJ} / \mathrm{d}) \\
\text { Assumed } \\
\text { Corrected } \\
\text { From acetate }\end{array}$ & - & $\begin{array}{r}9849 \\
9272 \\
0\end{array}$ & $\begin{array}{l}9565^{*} \\
9431 \\
1318\end{array}$ & $\begin{array}{l}9661 \mathrm{NS} \\
9217 \\
\text { r } 987\end{array}$ & $\begin{array}{r}100 \\
96 \\
-\end{array}$ \\
\hline $\begin{array}{l}\text { Wt of body and components } \\
\text { Initial live wt } \\
\text { Final live wt } \\
\text { Empty-body-wt }\end{array}$ & $\frac{18 \cdot 3}{14 \cdot 1}$ & $\begin{array}{l}18 \cdot 3 \\
42 \cdot 8 \\
34 \cdot 0\end{array}$ & $\begin{array}{l}18 \cdot 3 \\
42 \cdot 9 \\
33 \cdot 6\end{array}$ & $\begin{array}{l}18 \cdot 3 \\
42 \cdot 7 \\
32 \cdot 8\end{array}$ & - \\
\hline $\begin{array}{l}\text { Hot-carcass } \\
\text { Non-carcass remainder } \\
\text { Skin } \\
\text { Wool fibre } \\
\text { Wool grease } \\
\text { Blood } \\
\text { Head + feet } \\
\text { Gastrointestinal tract }+t \\
\text { Pluck }+ \text { t }\end{array}$ & $\begin{array}{l}8.1 \\
5.7 \\
0.6 \\
0.24 \\
0.03 \\
0.82 \\
1.80 \\
1.94 \\
0.83\end{array}$ & $\begin{array}{l}2 I \cdot 0 \\
10 \cdot 9 \\
2 \cdot 2 \\
I \cdot 02 \\
0 \cdot 14 \\
I \cdot 76 \\
2 \cdot 90 \\
4 \cdot 45 \\
I \cdot 74\end{array}$ & $\begin{array}{l}21 \cdot 2 \\
10 \cdot 4 * \\
2 \cdot 0 \\
0 \cdot 93 \\
0 \cdot 12 \\
1 \cdot 59 \\
2 \cdot 94 \\
4 \cdot 31 \\
1 \cdot 55^{*} *\end{array}$ & $\begin{array}{l}20 \cdot 4 \\
10 \cdot 1 * * \\
2 \cdot 3 \\
1.02 \\
0.10^{*} \\
1 \cdot 74 \\
2 \cdot 95 \\
3.95^{*} \\
1 \cdot 46^{* * *}\end{array}$ & $\begin{array}{l}0.48 \\
0.21 \\
0.19 \\
0.09 \\
0.02 \\
0.09 \\
0.08 \\
0.18 \\
0.04\end{array}$ \\
\hline 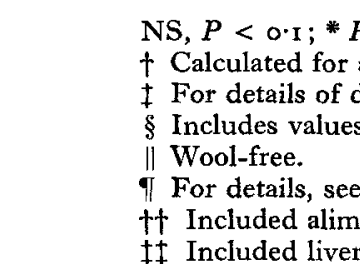 & $\begin{array}{l}* * P \\
\text { of } 18 \\
\text { Table } \\
\text { alty kill } \\
\text { act, blo } \\
\text { ungs, tr }\end{array}$ & $\begin{array}{l}\text { I ; *** } P \\
\text { d pp. } 345 \\
\text { at } 43.9 \mathrm{~kg} \\
\text { abdomina } \\
\text { ea. }\end{array}$ & $\begin{array}{l}<0.00 x \\
-6 . \\
\text { instead of } 45 \\
1 \text { fat, pancrea }\end{array}$ & $5 \mathrm{~kg}$. & rgans. \\
\hline
\end{tabular}

proportion of dietary acetate was increased. When the non-carcass remainder was analysed as its four components (head + feet, pluck (liver, heart, lungs, trachea), blood and gastrointestinal tract), about two-thirds of this decrease could be accounted for by the gastrointestinal tract component (alimentary tract, blood, abdominal fat, pancreas, spleen, sex organs), and one-third by the pluck. There was a significant decrease in the weight of wool grease as the level of acetate was increased, although it should be emphasized that this merely represents the difference between secretion into, and loss from, the pelt. The pelts (skin + wool) of the animals given the acetate-I 4 diet contained about $0.5 \mathrm{~kg}$, and of those given the acetate- $\mathrm{I} 9$ diet about I $\mathrm{kg}$ more moisture and dirt than did those of the control animals. This was probably because the animals on the salt diets drank more water and voided more urine, with the result that their pens quickly became fouled.

The rates of gain of empty-body-weight, and of hot-carcass and non-carcass remainder weights (Table 4) were all reduced by increasing the level of acetate, although the differences were significant only for the gain in weight of non-carcass remainder. When the composition of the gains was analysed, clear differences became apparent. As the amount of dietary energy contributed by acetate increased, the rate of fat 
Table 4. Expt I. Effect of diets containing I4 (acetate-14) or I9 (acetate-I9) \% of their metabolizable energy (ME) as acetate on growth rate of 10-week-old male lambs, and the composition of the gains made

\begin{tabular}{|c|c|c|c|c|}
\hline & & Diet† & & SE of difference \\
\hline & Control & Acetate-14 & Acetate-I9 & treatments $(n 8)$ \\
\hline Corrected $M E(\mathrm{~kJ} / \mathrm{d})$ & 9272 & 943 I & 9217 & 96 \\
\hline Rate of gain $(\mathrm{g} / \mathrm{d})$ & & & & \\
\hline Empty body & 169 & 160 & I 54 & 8.7 \\
\hline Hot-carcass & 109 & 107 & 101 & $5 \cdot 5$ \\
\hline Non-carcass remainder $\downarrow$ & 46 & $4 I^{*}$ & $39^{* *}$ & $2 \cdot 0$ \\
\hline Empty body & & & & \\
\hline Water & $86 \cdot 6$ & $84^{\circ} 9$ & $82 \cdot 7$ & 6.6 \\
\hline Protein $\S$ & $25^{\circ} 9$ & $24: 7$ & 25.0 & $\mathbf{r} \cdot 8$ \\
\hline Ash & $6 \cdot 5$ & $7 \cdot 6$ & $7 \cdot 3$ & 0.7 \\
\hline Fat & $50 \cdot 3$ & $44 \cdot 5 *$ & $40 \cdot 2^{* *}$ & $2 \cdot 3$ \\
\hline Energy $(k J / d) \|$ & 2699 & $2423^{*}$ & $2280^{* *}$ & 100 \\
\hline $\begin{array}{l}* P<0.05, * * P<0.01 \text {. } \\
\dagger \text { For details of diets, see } \\
\ddagger \text { For details, see p. } 347 \text {. } \\
\$ \text { Nitrogen } \times 6.25 \text {, exclud } \\
\text { || Calculated from values } \\
\text { rotein, but not wool grease }\end{array}$ & $\begin{array}{l}\text { and pp. } 3 \\
\text { rotein. } \\
\text { lines, Re }\end{array}$ & nsadoun \& & Niekerk & ncludes \\
\hline
\end{tabular}

deposition decreased; the difference between the fat deposition with control and acetate-r9 treatments ( $10 \mathrm{~g} / \mathrm{d}$ ) was highly significant. There were no significant differences between dietary treatments in the rates of gain of water, protein or ash. The group given the acetate-I9 diet retained $15 \%$ less energy $(4 \mathrm{I} 8 \mathrm{~kJ})$ than the controls when given an almost identical amount of ME. Acetate reduced fat deposition both in the carcass, which contained about three-quarters of the total body fat, and in the non-carcass component.

There were no differences between treatments in the $\mathrm{Na}: \mathrm{N}$ and $\mathrm{K}: \mathrm{N}$ ratios for the carcasses; these values were (mean $\pm \mathrm{SE}$ of difference) $2 \cdot 34,2 \cdot 40,2 \cdot 4 \mathrm{I} \pm 0.08 \mathrm{mmol}$ $\mathrm{K} / \mathrm{g} \mathrm{N}$ and $\mathrm{I} \cdot 75, \mathrm{I} \cdot 80, \mathrm{I} \cdot 79 \pm 0.08 \mathrm{mmol} \mathrm{Na} / \mathrm{g} \mathrm{N}$ for the control, acetate- $\mathrm{I} 4$ and acetate- 19 treatments respectively. The values for $K: N$ ratio agree well with a mean value of $2 \cdot 38 \mathrm{mmol} \mathrm{K} / \mathrm{g} \mathrm{N}$ calculated from the values of Kirton \& Pearson (Ig63).

Utilization of dietary energy. Table 5 gives the energy balance results expressed on a metabolic body-weight basis. Median live weight was calculated as follows: the emptybody-weight of each animal at the mid-point of the experimental period was calculated and was converted into live weight (empty body + fleece + gastrointestinal tract contents) by using a factor derived from the final empty-body-weight and final live weight of the control animals. Therefore, median live weight has no bias due to differences in gut fill and wool contamination.

The efficiency with which dietary energy surplus to the requirement for maintenance was utilized for energy retention ( $k_{f}$; Agricultural Research Council, 1965), was calculated on the assumption that the requirement for maintenance was $3 \mathrm{I} I \mathrm{~kJ}$ corrected ME $/ \mathrm{kg}^{0 \cdot 75}$ per $\mathrm{d}$ (Expt 2). All calculations have been based on corrected ME, because this corrects for bias due to differences in digestibility and differences in heat 
Table 5. Expt I. Utilization of dietary energy by 10-week-old male lambs given the control diet (without acetate) or diets containing $\mathrm{I}_{4}$ (acetate-14) or 19 (acetate-19) \% of their metabolizable energy (ME) as acetate

\begin{tabular}{|c|c|c|c|c|}
\hline & \multicolumn{3}{|c|}{ Diet† } & \multirow{2}{*}{$\begin{array}{l}\text { SE of difference } \\
\text { between dietary } \\
\text { treatments }(n 8)\end{array}$} \\
\hline & Control & Acetate-14 & Acetate-r 9 & \\
\hline Median live wt $\left(\mathrm{kg}^{0 \cdot 75}\right) \ddagger$ & $52 \cdot 94$ & $12 \cdot 71$ & $12 \cdot 65$ & 0.14 \\
\hline \multicolumn{5}{|l|}{ Energy $\left(\mathrm{kJ} / \mathrm{kg}^{0.75}\right.$ per $\left.\mathrm{d}\right)$} \\
\hline Corrected ME intake & $7 \times 9$ & $743 \mathrm{NS}$ & 729 & 12 \\
\hline ME used for maintenance & 3 II & 3 II & $3 \mathrm{II}$ & - \\
\hline ME used for gain (A) & 408 & 432 & 418 & - \\
\hline ME retained $(B)$ & 210 & $190^{*}$ & I $80 * * *$ & 6 \\
\hline Efficiency, $h_{f}(100 \mathrm{~B} / \mathrm{A})$ & $51 \cdot 5$ & $44^{\circ} 5^{*}$ & $43 \cdot 4^{* *}$ & $2 \cdot 4$ \\
\hline \multicolumn{5}{|l|}{ Energy $\left(\mathrm{kJ} / \mathrm{kg}^{0 \cdot 75}\right.$ per $\left.\mathrm{d}\right)$} \\
\hline ME used for gain from basal & 408 & 370 & 337 & $x_{3}$ \\
\hline ME used for gain from acetate & - & 62 & 81 & 2 \\
\hline ME retained from basal & 210 & I9I & I74 & 7 \\
\hline ME retained from acetate & - & $-I$ & 6 & II \\
\hline$k_{f}$ of acetate $\S$ & - & $3 \cdot 0$ & ro.I & $18 \cdot 1$ \\
\hline
\end{tabular}

$k_{f}$, Units of energy retained per 100 units of energy given above the maintenance requirement (Agricultural Research Council, r965).

NS, $P<0.1 ; * P<0.05$; ** $P<0.01$; *** $P<0.001$.

+ For details of diets, see Table I and pp. 345-6.

$\ddagger$ For details of calculation, see p. 352 .

$\S$ These values represent the means of individually calculated $k_{f}$ values, therefore do not correspond exactly with the other values given.

of fermentation. There was a clear and significant decrease in $k_{f}$ as the level of dietary acetate was increased, and an attempt was made to calculate the $k_{f}$ of acetate. The method of calculation used was to estimate the energy retention to be expected from the basal constituents of each diet and to attribute any difference to energy retention from the acetate salts. The calculated values were then analysed by a normal analysis of variance. The $k_{f}$ of the basal constituents of the acetate diets was assumed to be that of the control $\left(5 \mathrm{I}^{\cdot} 5\right)$, and it was also assumed that the partition of nutrients between maintenance and production was the same for the basal constituents and acetate. The $k_{f}$ values for acetate given in Table 5 indicate that the utilization of acetate calculated by this method was very poor, and that there were no significant differences between results with the two acetate diets. It should be emphasized that the errors implicit in this type of calculation are very large, and the individual $k_{f}$ values for acetate ranged from -66 to +52 .

\section{Expt 2. Indirect calorimetry}

Metabolizability of diets. Results are given in Table 6. All ME values were corrected for heat of fermentation, thus:

$\mathrm{ME}=$ gross energy - faecal energy - urine energy $-\mathrm{I} \cdot 8 \times$ methane energy (Blaxter, I967a).

There were no significant differences between diets in their metabolizability when this was expressed as a proportion of the basal (barley + soya-bean meal + fish meal + 
Table 6. Expt 2. Utilization of dietary energy by 6-month-old wether lambs given the diets containing 4 (control) or 16 (acetate) \% of their metabolizable energy (ME) as acetate, at two levels of feeding (low and high)

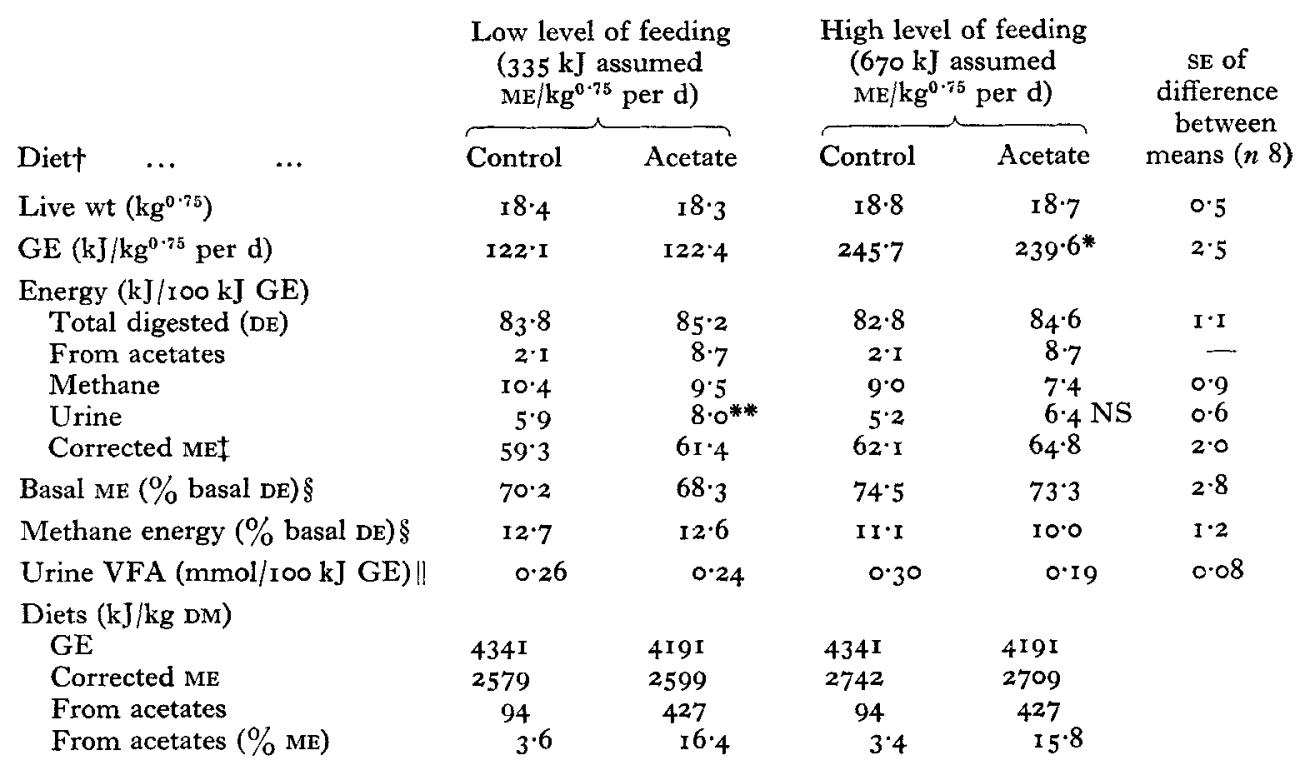

VFA, volatile fatty acids; GE, gross energy; $\mathrm{DE}$, digestible energy.

NS, $P<0.1$; $* P<0.05$; ** $P<0.01$.

+ For details of diets, see Table $I$ and pp. 345-6.

\$ ME corrected for heat of fermentation ( $80 \%$ methane energy (Blaxter, I $967 a$ )).

$\$$ Calculated for basal constituents assuming acetates $100 \%$ absorbed.

II By Markham distillation of urine (see p. 348); all VFA calculated as acetic acid.

straw) component. Corrected ME amounted to $74 \cdot 5$ and $73.3 \%$ digestible energy (DE) of the basal component of the control and acetate diets respectively at the high level of feeding. An average value of $74 \% \mathrm{DE}$ was used in the calculation of corrected $\mathrm{ME}$ for Expt I (Table 2). The acetate diet produced significantly $(P<0.05)$ greater losses of energy in the urine, although these were quantitatively small ( $\mathrm{I}-2 \% \mathrm{DE})$. The difference was not due to differences in the amount of VFA in the urine or of urinary $N$ (Table 6). Nor were the differences due to ketones, for the difference calculated as acetone would have been equivalent to a concentration of $2 \cdot 7-3 \cdot 4 \mathrm{mmol} / \mathrm{l}$ urine, which is within the stated sensitivity of the method used to analyse the urine. No further analyses were undertaken; therefore the reason for the greater loss of urine energy from the acetate diet is not known.

Fasting catabolism. Fasting catabolism (heat production + energy lost in the urine) was used as the measure of basal metabolism in all the calculations made here, and was defined as the energy catabolism which occurred during the period between 88 and $13^{6} \mathrm{~h}$ after the last meal. During this period methane production was less than $21 / 24 \mathrm{~h}$. The lambs were fed at the maintenance level for at least $\mathrm{I}$ week before being fasted. The results for the two fasting periods are given in Table 7 .

Utilization of ME. Values for the efficiency with which ME was utilized to spare the 
Table 7. Expt 2. Fasting catabolism ( $k \mathcal{F} / \mathrm{kg}^{0 \cdot 75}$ per $\left.d\right)$ of 6-month-old wether lambs fasted at the beginning (fasting period $\mathrm{I}$ ) and end (fasting period 2) of the experiment*

\begin{tabular}{|c|c|c|c|c|c|c|c|c|c|}
\hline \multirow[b]{2}{*}{ Lamb } & \multicolumn{4}{|c|}{ Fasting period I } & \multicolumn{4}{|c|}{ Fasting period 2} & \multirow[b]{2}{*}{ Mean } \\
\hline & $\begin{array}{c}\text { Wt } \\
\left(\mathrm{kg}^{0 \cdot 75}\right)\end{array}$ & Heat & Urine & Total & $\begin{array}{c}W_{t} \\
\left(\mathrm{~kg}^{0-75}\right)\end{array}$ & Heat & Urine & Total & \\
\hline A & $16 \cdot 36$ & 240 & 22 & 262 & $2 I \cdot 35$ & $23 I$ & 16 & 247 & 255 \\
\hline $\mathbf{B}$ & 16.44 & 247 & 23 & 270 & $20-70$ & 235 & 13 & 249 & 259 \\
\hline C & 14.95 & $2 \times 6$ & I5 & $23 r$ & $18 \cdot 95$ & 232 & 17 & 249 & 240 \\
\hline $\mathrm{D}$ & 15.67 & 249 & $3 I$ & 279 & $20 \cdot 37$ & 230 & 21 & 249 & 265 \\
\hline Mean & 15.86 & 238 & 23 & 260 & $20 \cdot 34$ & 232 & 17 & 248 & 255 \\
\hline
\end{tabular}

catabolism of body energy reserves when the animal was at or below energy equilibrium ( $k_{m}$; Agricultural Research Council, 1965) and $k_{f}$ (the efficiency of ME utilization for energy retention) are given in Table 8.

Maintenance. The $k_{m}$ values given in Table 8 were calculated for individual determinations as:

$$
k_{m}=\frac{\text { fasting catabolism - energy loss }}{\text { corrected ME intake }} \times \text { I } 00 .
$$

Fasting catabolism was corrected for time with the assumption that the change between fasting periods $\mathrm{I}$ and 2 was linear. The $k_{f}$ and $k_{m}$ values given in Table 8 are the means of the average value (treatment periods $I$ and 2) calculated for each lamb, with the exception of the $k_{m}$ for the acetate diet, which is the mean of three lambs only. Only one measurement was made on one of the lambs with the acetate diet at the low level of feeding and the $k_{m}$ calculated was $59.7 \%$. This value was excluded from the mean, since it was twenty units below the values obtained with the other three lambs.

There was no significant difference between diets, and the results were combined to give one value $\left(k_{m} 8 \mathrm{I} \cdot 9 \pm \mathrm{I} \cdot 7 \%\right)$. This value when combined with the mean fasting catabolism gave a maintenance requirement of $3 \mathrm{II} \mathrm{kJ}$ corrected $\mathrm{ME} / \mathrm{kg}^{0.75}$ per $\mathrm{d}$; this value was used in all calculations in Expt I.

Fattening. The $k_{f}$ values were calculated for individual determinations as:

$$
k_{f}=\frac{\text { energy retained }}{\text { total } \mathrm{ME}-\left(\frac{\text { fasting catabolism }}{0.01 \times k_{m}}\right)} \times 100 \text {, }
$$

and mean values were obtained as described previously for $k_{m}$. Fasting catabolism was again adjusted for time, and the $k_{m}$ value used was that obtained with the same animal with the same diet for the same treatment period ( 1 or 2 ). The differences between diets were small and not statistically significant.

$N$ balance. There were no differences between diets in the amount of $\mathrm{N}$ retained (Table 9). Values for treatment periods I and 2 compared very well. The amounts of $N$ retained corresponded to about $I I-I 2$ and $3^{8-40} \mathrm{~g}$ protein/d at the low and high levels of feeding respectively (equivalent to about $2 \mathrm{I} \%$ energy retained). These values compared with about $6 \mathrm{~g}$ wool fibre/d and $25 \mathrm{~g}$ body protein/d by the control animals in Expt $\mathrm{I}$ ( $26 \%$ energy retained). 
Table 8. Expt 2. Utilization of corrected metabolizable energy (ME) by 6-month-old wether lambs given the diets containing 4 (control) or 16 (acetate) \% of their metabolizable energy (ME) as acetate, at two levels of feeding (low and high)

\begin{tabular}{|c|c|c|c|c|c|c|c|c|}
\hline \multirow[b]{2}{*}{ Diet* } & \multicolumn{2}{|c|}{$\begin{array}{l}\text { Low level of feeding } \\
(335 \mathrm{~kJ} \text { assumed } \\
\left.\mathrm{ME} / \mathrm{kg}^{0 \cdot 75} \text { per } \mathrm{d}\right)\end{array}$} & \multicolumn{2}{|c|}{$\begin{array}{l}\text { High level of feeding } \\
(670 \mathrm{~kJ} \text { assumed } \\
\left.\mathrm{ME} / \mathrm{kg}^{0.75} \text { per } \mathrm{d}\right)\end{array}$} & \multirow{3}{*}{$\begin{array}{l}S E \\
0.49\end{array}$} & \multicolumn{2}{|c|}{ Treatment period } & \multirow[b]{2}{*}{$\mathrm{SE}$} \\
\hline & Control & Acetate & Control & Acetate & & I & 2 & \\
\hline Live wt $\left(\mathrm{kg}^{0 \cdot 25}\right)$ & $18 \cdot 37$ & $18 \cdot 27$ & $18 \cdot 80$ & $18 \cdot 67$ & & $18 \cdot 38$ & 18.68 & 0.35 \\
\hline $\begin{array}{l}\text { Energy }\left(\mathrm{kJ} / \mathrm{kg}^{0.75} \text { per } \mathrm{d}\right) \\
\text { Corrected ME intake } \uparrow \\
\text { Heat production (corrected) } \dagger \\
\text { Balance }\end{array}$ & $\begin{array}{l}303 \\
308 \\
-5\end{array}$ & $\begin{array}{r}316 \\
325 \\
-9\end{array}$ & $\begin{array}{l}638 \\
420 \\
218\end{array}$ & $\begin{array}{l}648 \\
442 \\
206\end{array}$ & $\begin{array}{l}\text { I7 } \\
\text { I } 2 \\
\text { ro }\end{array}$ & $\begin{array}{r}474 \\
379 \\
95\end{array}$ & $\begin{array}{l}478 \\
369 \\
\text { Iog NS }\end{array}$ & $\begin{array}{r}\text { I I } \\
9 \\
7\end{array}$ \\
\hline $\begin{array}{l}\text { Efficiency }(\%) \\
\text { Maintenancef } \\
\text { Fatteningt }\end{array}$ & $82 \cdot 4 \pm 2 \cdot 3$ & $8 \mathrm{I} \cdot 2 \pm 0.7$ & $\frac{-}{67 \cdot 4 \pm 4.5}$ & $65 \cdot \overline{8 \pm 2 \cdot 7}$ & - & - & - & - \\
\hline
\end{tabular}

Table 9. Expt 2. Nitrogen balance of 6-month-old wether lambs given the diets containing 4 (control) or $\mathrm{I} 6$ (acetate) \% of their metabolizable energy (ME) as acetate, at two levels of feeding (low and high)

\begin{tabular}{|c|c|c|c|c|c|c|c|c|}
\hline \multirow[b]{2}{*}{ Diet* } & \multicolumn{2}{|c|}{$\begin{array}{l}\text { Low level of feeding } \\
(335 \mathrm{~kJ} \text { assumed } \\
\left.\mathrm{ME} / \mathrm{kg}^{0 \cdot 75} \text { per } \mathrm{d}\right)\end{array}$} & \multicolumn{2}{|c|}{$\begin{array}{l}\text { High level of feeding } \\
(670 \mathrm{~kJ} \text { assumed } \\
\mathrm{ME} / \mathrm{kg}^{\mathrm{o} \cdot 25} \text { per d) }\end{array}$} & \multirow{2}{*}{$\begin{array}{l}\text { SE of } \\
\text { difference } \\
\text { between } \\
\text { means }\end{array}$} & \multicolumn{2}{|c|}{$\begin{array}{l}\text { Treatment } \\
\text { period }\end{array}$} & \multirow{2}{*}{$\begin{array}{l}\text { SE of } \\
\text { difference } \\
\text { between } \\
\text { means }\end{array}$} \\
\hline & Control & Acetate & Control & Acetate & & I & 2 & \\
\hline \multicolumn{9}{|l|}{$\mathrm{N}(\mathrm{mg} / \mathrm{I} 00 \mathrm{~kJ} \mathrm{ME})$} \\
\hline Ingested & $28 I$ & 276 & 259 & 265 & 9 & 272 & 269 & 6 \\
\hline Digested & 239 & 234 & 226 & 212 & 7 & 228 & 228 & 5 \\
\hline Urine & 196 & 202 & 179 & I57 & - & 184 & 182 & - \\
\hline Retained & 43 & 33 & 47 & 54 & I I & 44 & 44 & 8 \\
\hline $\begin{array}{l}\text { Retained N } \\
\left(\mathrm{mg} / \mathrm{kg}^{0 \cdot 75} \text { per d) }\right.\end{array}$ & I I 9 & 72 & 348 & 342 & 48 & $22 I$ & 220 & 34 \\
\hline
\end{tabular}

\section{Expt 3. Rumen VFA and cations}

The $\mathrm{pH}$ levels of the digesta are shown in Fig. 2. The differences between diets were clear, the reduction in $\mathrm{pH}$ after feeding became progressively less marked as the proportion of acetate in the diet was increased. Total VFA concentrations are also shown in Fig. 2. There were large diurnal fluctuations when the acetate diets were fed, which tended to reflect the pattern of eating. The control and acetate-I4 diets were usually completely consumed by the time the fourth sample was taken, whereas the acetate-19 diet was only about two-thirds eaten by this time, the balance being eaten before the evening meal. This pattern was similar to that obtained (subjectively) with the lambs used in Expt $\mathrm{I}$. The mean values for $\mathrm{pH}$ and VFA concentration as well as 


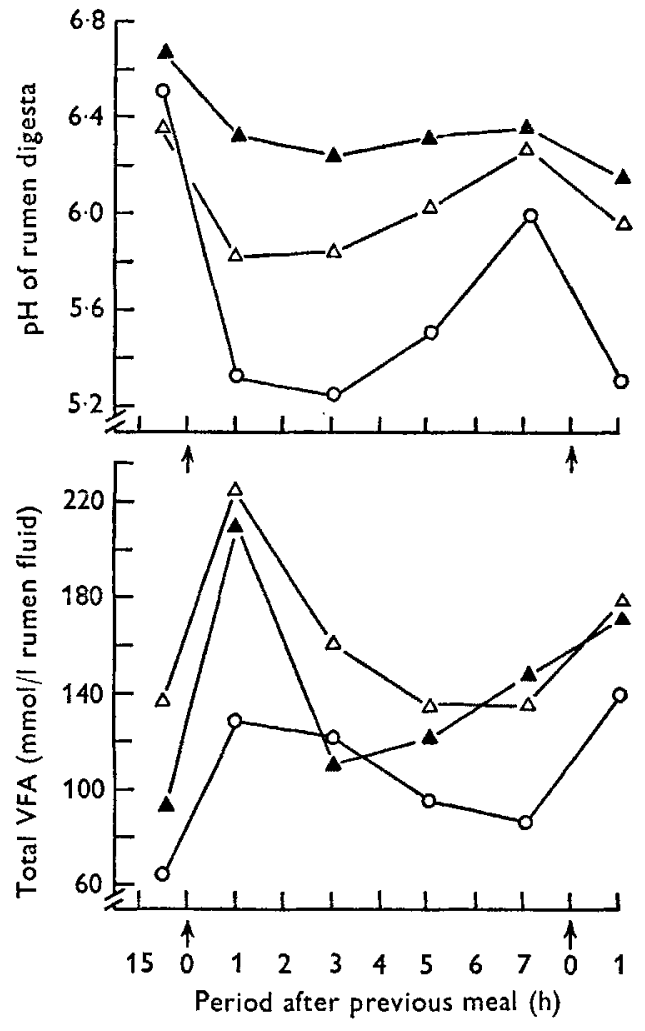

Fig. 2

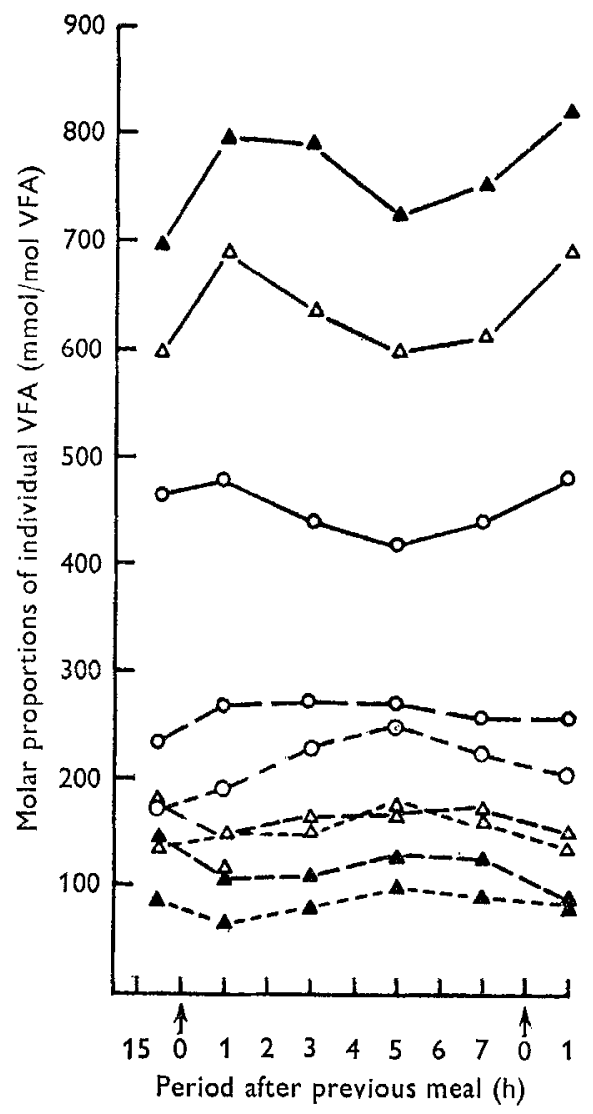

Fig. 3

Fig. 2. Expt 3. Rumen $\mathrm{pH}$ and total volatile fatty acids (VFA) (mmol/1) in rumen fluid from 2-year-old wether sheep given a control diet (without acetate) $(O)$ or diets containing $I_{4}(\triangle)$ or $I_{9}(\Delta) \%$ of their metabolizable energy as acetate (for details of diets, see Table $I$ and pp. 345-6). Each point is the mean value for three sheep. $\uparrow$, Daily ration fed at two equal meals (08.30 and $\mathrm{r} 6.30$ hours).

Fig. 3. Expt 3. Molar proportions ( $\mathrm{mmol} / \mathrm{mol}$ volatile fatty acids (VFA)) of acetic (- - ), propionic $(--)$ ) and $n$-butyric (---) acids in rumen fluid of 2 -year-old wether sheep given a control diet (without acetate) $(O)$ or diets containing $14(\Delta)$ or $19(\Delta) \%$ of their metabolizable energy as acetate (for details of diets, see Table 1 and pp. 345-6). Each point is the mean value for three sheep. $\uparrow$, Daily ration fed at two equal meals (08.30 and 16.30 hours).

molar proportions of rumen VFA are given in Table io; diurnal fluctuations of the latter are shown in Fig. 3. The addition of acetate to the diet resulted in large increases in rumen acetate with concomitant decreases in the other VFA. In an attempt to determine whether the fermentation pattern was altered, the $n$-butyrate:propionate ratio was calculated (Table Io); no significant differences were apparent.

Rumen cation concentrations are shown in Fig. 4. Na and $\mathrm{K}$ concentrations remained very constant; the increase in $\mathrm{Na}$ after feeding was rapidly eliminated by dilution (drinking) and absorption. $\mathrm{Ca}$ concentrations in the rumen were increased considerably by the acetate diets, although the difference between the two acetate diets was not statistically significant. 
Table Io. Expt 3. Volatile fatty acid $(V F A)$ and cation concentrations in the rumen of 2-year-old wether sheep given the control diet (without acetate) or diets containing $\mathrm{I}_{4}$ (acetate-14) or $\mathrm{I}_{9}$ (acetate-19) \% of their metabolizable energy as acetate

\begin{tabular}{|c|c|c|c|c|}
\hline & \multicolumn{3}{|c|}{ Diet } & \multirow{2}{*}{$\begin{array}{c}\text { SE of } \\
\text { difference } \\
\text { between } \\
\text { means }(n \text { 3) }\end{array}$} \\
\hline & Control & Acetate-14 & Acetate-I9 & \\
\hline Rumen pH & $5 \cdot 65$ & $6 \cdot 06$ & $6 \cdot 32$ & 0.21 \\
\hline VFA (mmol/1) & 106 & $163^{* *}$ & $142 * *$ & $3 \cdot 2$ \\
\hline $\begin{array}{l}\text { Molar composition (r } \\
\text { Acetic } \\
\text { Propionic } \\
n \text {-Butyric } \\
\text { Isobutyric } \\
n \text {-Valeric } \\
\text { Isovaleric } \\
\text { Caproic }\end{array}$ & $\begin{array}{r}449 \\
253 \\
208 \\
21 \\
32 \\
24 \\
14\end{array}$ & $\begin{array}{l}634 \\
162 \\
\text { r44** } \\
\text { I5 } \\
\text { I5** } \\
25 \\
6\end{array}$ & $\begin{array}{l}762^{*} \\
115 \\
79^{* *} \\
12^{*} \\
10^{* *} \\
16 \\
4\end{array}$ & $\begin{array}{r}56 \cdot 6 \\
67 \cdot 2 \\
8 \cdot 3 \\
2 \cdot 2 \\
2 \cdot 1 \\
6 \cdot 2 \\
4 \cdot 8\end{array}$ \\
\hline n-Butyric:propionic & $9 \cdot 2$ & 10.4 & $8 \cdot I$ & $4^{6}$ \\
\hline $\begin{array}{l}\text { Digesta: } \\
\text { DM }(\mathrm{g} / \mathrm{kg}) \\
\text { Ash }(\mathrm{g} / \mathrm{kg} \mathrm{DM})\end{array}$ & $\begin{array}{l}\text { I59 } \\
\text { I I } 3\end{array}$ & $\begin{array}{l}102 * \\
212^{* *}\end{array}$ & $\begin{array}{c}75^{*} \\
238^{* *}\end{array}$ & $\begin{array}{r}13.8 \\
9.7\end{array}$ \\
\hline $\begin{array}{l}\text { Cations (mmol } / \mathrm{kg} \mathrm{di} \\
\text { Sodium } \\
\text { Potassium } \\
\text { Calcium }\end{array}$ & $\begin{array}{r}103 \\
48 \\
44 \\
\\
\text { ts, see T }\end{array}$ & $\begin{array}{l}\text { I I } 4 \\
47 \\
102 * *\end{array}$ & $\begin{array}{l}\text { I } 13 \\
49 \\
80^{* *}\end{array}$ & $\begin{array}{l}7 \\
6 \\
3 \cdot 5\end{array}$ \\
\hline
\end{tabular}

\section{DISCUSSION}

Metabolizability of diets. There was no evidence from any of the experiments that the metabolizability of the diets was significantly altered by the substitution of salts of acetic acid for fermentable carbohydrate if the energy of the salts was assumed to be completely absorbed. High levels of $\mathrm{Na}$ have been found to inhibit fermentation in vitro (Walker \& Forest, 1964). However, the rapid rate at which rumen $\mathrm{Na}$ was equilibrated suggests that, at the levels of $\mathrm{Na}$ supplementation used here, inhibition in vivo would have been minimal. Differences in the digestibility of the basal constituents of the diets were small and not statistically significant and there were no differences in methane production in Expt 2. The fact that the $n$-butyric:propionic acid ratio remained relatively constant also suggests that the fermentation of the basal constituents was not drastically altered by the addition of the salts. There was some evidence of very slightly higher losses of energy in the urine when diets containing acetates were given, although the energy lost did not appear to be in the form of VFA or ketones. At the high level of feeding in Expt 2 corrected ME was $73.9 \pm 1.5 \%$ DE (basal constituents) or $82.3 \%$ DE when not corrected for heat of fermentation, which agrees well with the value of $82 \%$ DE estimated from the values of Blaxter $(1967 b)$.

$N$ retention. There was no effect of acetate on $\mathrm{N}$ retention, contrary to the reports of Rook et al. (1963), Ørskov \& Allen (1966c) and Vermorel (1968). 

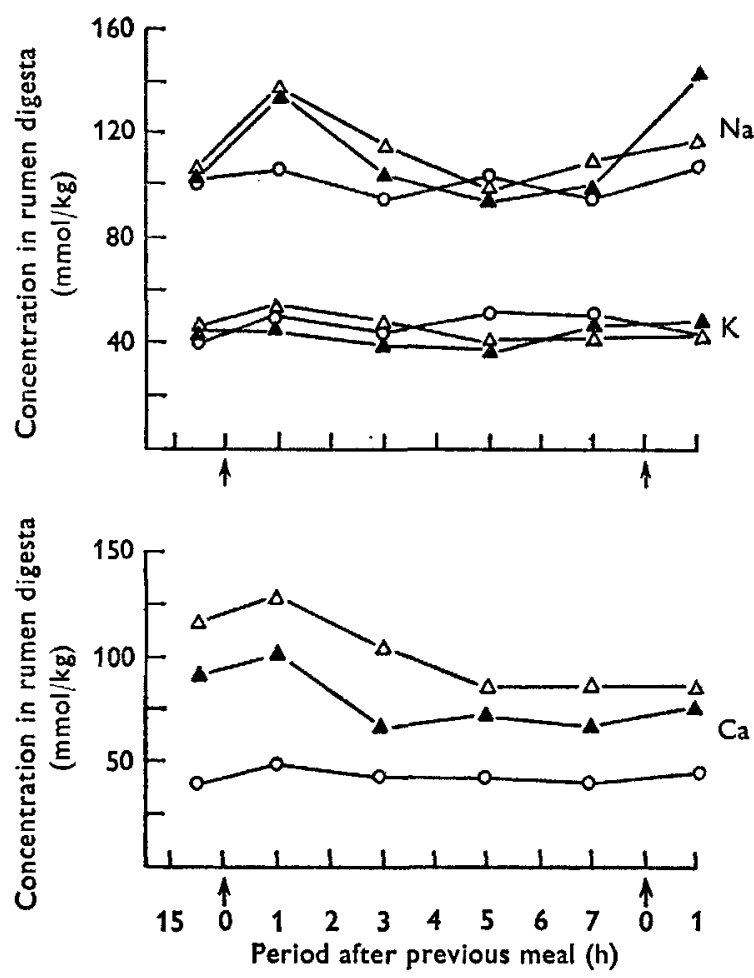

Fig. 4. Expt 3. Concentrations of sodium, potassium and calcium in rumen digesta of 2-year-old sheep given a control diet (without acetate) $(O)$ or diets containing $14(\triangle)$ or $19(\Delta) \%$ of their metabolizable energy as acetate (for details of diets, see Table I and pp. 345-6). Each point is the mean value for three sheep. $\uparrow$, Daily ration fed at two equal meals (08.30 and $16.3 \circ$ hours).

Utilization of ME for maintenance. The combined value of $k_{m}$ for the two diets used in Expt 2 was $81.9 \pm 1.7 \%$ and is in good agreement with that of $82.3 \%$ given by Blaxter ( $1967 a$ ). Fasting catabolism at $255 \pm$ i $\mathrm{kJ} / \mathrm{kg}^{0.73}$ per $\mathrm{d}$ (heat production plus $20 \mathrm{~kJ}$ lost in urine) was not significantly lower than the value of $255 \mathrm{~kJ} / \mathrm{kg}^{0.75}$ per d for the fasting metabolism (heat production only) of a 6-month-old lamb calculated from the preferred value of $264 \mathrm{~kJ} / \mathrm{kg}^{0} \cdot 73$ per $\mathrm{d}$ given by the Agricultural Research Council ( 1965$)$ for a lamb of $40 \mathrm{~kg}$ live weight.

Utilization of ME for energy retention. There are several possible reasons for the difference between experiments in the $k_{f}$ of the control diets, the most likely of which is that the lambs confined within the respiration chamber had a lower maintenance requirement than that of the less closely confined and young lambs of Expt $\mathrm{r}$, which were also exposed to the draughts and other vicissitudes of the sheep house. Ørskov \& McDonald (1970) estimated the maintenance requirement of such lambs to be $4 \mathrm{r} 8 \mathrm{~kJ}$

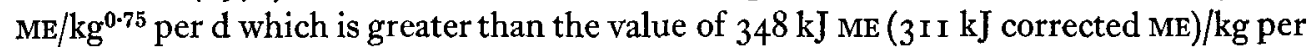
$\mathrm{d}$ used here. The lambs used in Expt 2 were 3-4 months older and might be expected to have had a slightly lower maintenance requirement (Agricultural Research Council, 1965). Furthermore, balance experiments and slaughter experiments have errors 
which tend to accumulate to values of the same order as the differences reported here. Although the use of a different value for maintenance will alter the $k_{f}$ value of the diets, it has less effect on $k_{f}$ of the acetate as this is calculated by difference.

The poor utilization of ME found in Expt I with the acetate diets is in agreement with the conclusion of Armstrong \& Blaxter (1957) that acetate is poorly utilized for lipogenesis. It is not in agreement with the findings of Ørskov \& Allen (1966a,b,c), Ørskov et al. (1966), Poole \& Allen (1970) and Bull et al. (1970). However, in Expt 2 no differences were found between the $k_{f}$ values for the two diets. A recurrent problem in experiments in which the utilization of dietary energy is determined is one of precision. In the comparative slaughter experiment reported here no statistically significant differences were found until chemical analysis was used as a means of assessment (apart from the gain in weight of the non-carcass remainder). The control group gained $15 \mathrm{~g}$ empty-body-weight/d more than the acetate-19 group, a difference which was not statistically significant. However, two-thirds of this difference was due to the differences in fat deposition, which was statistically highly significant. There were also large errors in the calorimetry experiment. The $k_{f}$ of the acetate in the acetate diet was calculated, by the difference method used in Table 6 , to be $54 \%$. However, statistically this value could have been I I or $96 \%$. Similar calculations made from the values of Bull et al. (1970) suggest that their experiment was not sensitive enough to detect differences between acetate utilized with an efficiency of $67 \%$ (the value obtained), and about $44 \%$. A final indication of the problems of experimental precision and interpretation is provided by the fact that the $k_{f}$ values obtained in Expt I were calculated on the assumption that the maintenance requirement was $3 \mathrm{Ir} \mathrm{kJ} \mathrm{ME} / \mathrm{kg}^{0.75}$ per d, which was estimated from the mean value of $k_{m}$ for the two diets used in Expt 2. If this mean value is used to recalculate the $k_{f}$ value for the two diets used in Expt 2, then that of the control diet is estimated as 66.7\% and that of the acetate diet as $61 \cdot 1 \%$, and although these values do not differ significantly (given the same errors), the $k_{f}$ value for the additional acetate of the acetate diet then becomes $21 \%$.

Bull et al. (1970) suggested that a possible reason for the differences between the original infusion experiments of Armstrong and his colleagues (Armstrong \& Blaxter, I957; Armstrong et al. 1958), and the various comparative slaughter experiments reported, was that there was adaptation by the animals to high levels of acetate, the adaptation taking longer than the $5^{-7} \mathrm{~d}$ duration of the original infusion experiments. The comparative slaughter experiment reported here lasted over 14 weeks, which is considerably longer than the 8-15d suggested by Bull et al. (1970) as being the time necessary for adaptation. A small difference in energy retention which approached statistical significance was found between treatment periods $\mathbf{I}$ and 2 in Expt 2. However, this was removed if an adjustment was made for maintenance, which suggests that the differences in heat production were associated with the activity of the animals rather than with metabolic adaptation, and that treatment period $\mathrm{I}$ acted as a retraining period for treatment period 2.

Armstrong et al. (1958) calculated expected values for the $k_{f}$ of VFA mixtures from the values they obtained for the individual acids. These expected values were 
based on the molar proportions of the mixtures, but Ørskov (1965) recalculated them from the energy proportions. The recalculated value he obtained for an acetatepropionate-butyrate mixture containing molar proportions of $75: 15: 10$ (corresponding energy proportions 59:21:20) was $43 \cdot 6 \pm 2 \cdot 7 \%$; the value obtained with this mixture $(3 \mathrm{I} \cdot 8 \pm \mathrm{I} \cdot 8 \%)$ was significantly lower. However, the expected and 'observed' $k_{f}$ values for a low-acetate mixture, containing $14 \%$ energy as acetate, were $55 \cdot 5 \pm 3 \cdot 2$ and $58 \cdot 2 \pm 1 \cdot 3 \%$ respectively, which did not differ significantly. The implication is that the utilization of acetate for lipogenesis is related to its contribution to the energy available. An attractive explanation of this is that the utilization of acetate for lipogenesis is dependent upon a supply of glucose sufficient to provide (by the pentose phosphate pathway) the NADPH necessary for fatty acid synthesis (see Armstrong, 1965; Blaxter, 1967a; Ballard, Hanson \& Kronfeld, 1969), although Ballard et al. (1969) comment 'Since acetate is utilized for lipogenesis in ruminant tissues in the absence of added glucose (in vitro) the source of reducing equivalents to support lipogenesis is in question'.

There is evidence that the ruminant can obtain NADPH from acetate by means of cytosolic isocitrate dehydrogenase (NADP) ( $E C$ I.I.I.42) in mammary tissue (Bauman, Mellenberger \& Derrig, 1973; Gumaa, Greenbaum \& McLean, 1973) and in adipose tissue (Ingle, Bauman \& Garrigus, 1972). Bauman et al. (1973) estimated that more than $50 \%$ of the NADPH required for fatty acid synthesis in ruminant mammary tissue might be produced from acetate in this way. The relative importance of this pathway and the pentose phosphate pathway for the provision of NADPH for fat synthesis by ruminant adipose tissue in vivo is difficult to evaluate. Ingle $e t$ al. (1972) indicated the difference between the ruminant and non-ruminant by calculating the activity ratio, glucose-6-phosphate dehydrogenase (EC I.I.I.49):isocitrate dehydrogenase (NADP) in calf, lamb and rat adipose tissue to be $1: 4,1: 2$ and $2: 1$ respectively, and suggested that these ratios might be indicative of the relative importance in the tissues of the pentose phosphate pathway and metabolism of acetate via isocitrate. A similar calculation from the results of Bauman, Brown \& Davis (1970) and those of Gumaa et al. (1973) respectively, gives the activity ratio, glucose-6-phosphate dehydrogenase:isocitrate dehydrogenase (NADP) to be $9: 1$, 4:I and $I: 13$ for rat, sow and cow mammary tissue respectively, and $20: I, I: I$ and I :6 for rat mammary, rat adipose and sheep mammary tissue respectively. Although there were inherent difficulties in relating different experiments, these values suggest that the disparity between ruminants and non-ruminants is greatest in mammary tissue. Balmain, Folley \& Glascock (1954) found that whereas rat mammary tissue responded to insulin by increasing the incorporation of both acetate- and glucose- $\mathrm{C}$ into fatty acid, sheep mammary tissue had no response, and suggested that this represented a true species difference. Ruminant adipose tissue, however, does respond to insulin; Škarda \& Bartoš (1969) found that the incorporation of acetate-C into fatty acid, and the oxidation of glucose by goat adipose tissue in vitro were both increased by insulin, and suggested that this was due to stimulation of the pentose phosphate pathway. It is therefore possible that a real difference exists between ruminant adipose tissue and ruminant mammary tissue in the relative importance of 
the pentose phosphate pathway and cytosolic isocitrate dehydrogenase (NADP) for the generation of NADPH. The metabolism of acetate for the generation of NADPH by the pathway proposed by Bauman et al. (I973) would also generate other ATP equivalents. Presumably this energy could be usefully utilized by the mammary gland for the many other processes associated with milk synthesis and secretion, but might prove an embarrassment to adipose tissue if relatively large amounts of NADPH were generated from acetate. If this is the situation, then the efficient utilization of large amounts of acetate for lipogenesis by ruminant adipose tissue will require sufficient glucose for the provision of most of the necessary NADPH. Another possibility is that the glucose:acetate ratio may be important in initiating lipogenesis or lipolysis (see Sutherland, 1967 ). Both these hypotheses imply that as the contribution of acetate to $\mathrm{ME}$ available for lipogenesis increases, an increasing proportion of acetate is wastefully oxidized, and the average efficiency of utilization decreases. This relationship between the utilization of acetate and the relative amount available provides a very satisfactory explanation for many of the published results discussed earlier (see p. 360). The use of triacetin by Bull et al. (1970) ensured that one $C_{3}$ molecule was provided for every three $C_{2}$ molecules, more than sufficient glucose precursor for the NADPH and glycerol synthesis necessary to utilize the acetate given; therefore the efficient utilization of triacetin-acetate was to be expected. The finding of Ørskov \& Allen (1966c) and Poole \& Allen (1970) that acetate included in a high-concentrate diet was better utilized than when included in a high-fibre diet is also relevant, since the highconcentrate diets should have provided more glucose precursor in the form of propionate.

Notwithstanding the problems of precision discussed earlier, if the difference between the experiments reported here was real, then a possible explanation might be that in Expt 2 the relationship between acetate and glucose was nearer to the optimum for efficient lipogenesis. There are no obvious reasons why this should have occurred. The diets were practically identical except for the fact that in Expt 2 the barley was ground, and a small proportion of chopped straw was included. Whether this resulted in a different fermentation pattern, or an increase in the proportion of $\alpha$-linked glucose which reached the small intestine is not known. There may have been differences in the pattern of eating, for although no records were taken of eating behaviour, it was observed that the lambs in Expt 2 tended to nibble their ration over most of the day, whereas those in Expt I tended to consume their ration as discrete meals. If the utilization of acetate is related to the availability of glucose or glucose precursor and if, as suggested by McClymont (1952), the utilization of acetate at any moment in time is as a partition between lipogenesis and oxidation, then a large meal of rapidly absorbed acetate would be inefficiently utilized, and a situation of glucose shortage aggravated.

It must be emphasized that there is no direct evidence that there is any interaction between acetate and other metabolites, apart from the infusion results of Armstrong et al. (1958) already discussed, and the disagreement between Expts I and 2 may have been due to the errors already described, or to there having been large losses of energy in the urine, or disproportionate losses as methane by the lambs given the acetate 
diets in Expt I. However, some experimental evidence of a non-linear relationship between the utilization of acetate and its contribution to ME will be provided in another paper.

This work was carried out when one of us (F.D.DeB.H.) was in receipt of a Research Fellowship awarded by British Petroleum Chemicals (UK) Ltd, Devonshire House, Mayfair Place, London, who also donated the salts. We are grateful to $\mathrm{Mr} \mathrm{N}$. Mackie who prepared the computer programmes used to process the results, to Messrs K. Gifford and I. McHattie for technical assistance, and to colleagues for helpful discussion.

\section{REFERENCES}

Agricultural Research Council (1965). The Nutrient Requirements of Farm Livestock No. 2, Ruminants. London: Agricultural Research Council.

Armstrong, D. G. (1965). In Physiology of Digestion in the Ruminant, p. 272 [R. W. Dougherty, editor]. Washington, DC: Butterworths.

Armstrong, D. G. \& Blaxter, K. L. (1957). Br. F. Nutr. Ix, $4{ }^{13}$.

Armstrong, D. G., Blaxter, K. L., Graham, N. McC. \& Wainman, F. W. (1958). Br. F. Nutr. $12,177$.

Association of Official Agricultural Chemists (1965). Official Methods of Analysis, 1oth ed. Washington, DC: Association of Official Agricultural Chemists.

Ballard, F. J., Hanson, R. W. \& Kronfeld, D. S. (1969). Fedn Proc. Fedn Am. Socs exp. Biol. $28,218$.

Balmain, J. H., Folley, S. J. \& Glascock, R. F. (1954). Biochem. F. 56, 234.

Bauman, D. E., Brown, R. E. \& Davis, C. L. (1970). Archs Biochem. Biophys. 140, 237.

Bauman, D. E, Mellenberger, R. W. \& Derrig, R. G. (1973). F. Dairy Sci. 56, r312.

Blaxter, K. L. (1967a). The Energy Metabolism of Ruminants, and ed. London: Hutchinson.

Blaxter, K. L. (1967b). In Proceedings of the First University of Nottingham Nutrition Conference, p. $3^{\circ}$ [H. Swan and D. Lewis, editors]. Loughborough: University of Nottingham.

Blaxter, K. L. \& Wainman, F. W. (1964). F. agric. Sci., Camb. 63, I13.

Brouwer, E. (1965). Publs Eur. Ass. Anim. Prod. no. I I, p. 44 I.

Bull, L. S., Reid, J. T. \& Johnson, D. E. (1 970). F. Nutr. 100, 262.

Davidson, J., Mathieson, J. \& Boyne, A. W. (1970). Analyst, Lond. 95, 181.

Evans, R. E. (1960). Bull. Minist. Agric. Fish. Fd, Lond. no. 48.

Gitelman, H. J. (r967). Analyt. Biochem. 18, 52 I.

Gumaa, K. A., Greenbaum, A. C. \& McLean, P. (r973). Eur. F. Biochem. 34, 88.

Hovell, F. D. DeB. (1972). The utilisation of salts of volatile fatty acids by growing lambs. PhD Thesis, University of Aberdeen.

Hovell, F. D. DeB. \& Greenhalgh, J. F. D. (1970). Proc. Nutr. Soc. 29, 28 A.

Hovell, F. D. DeB. \& Ørskov, E. R. (1972). F. agric. Sci., Camb. 7I, 54I.

Ingle, D. L., Bauman, D. E. \& Garrigus, U. S. (1972). F. Nutr. 102, 609.

Kirton, A. H. \& Pearson, A. M. (1963). F. Anim. Sci. 22, 125.

McClymont, G. L. (1952). Aust. Y. Sci. Res. B 5, 374.

Orskov, E. R. (r965). The utilization of volatile fatty acids by growing lambs. PhD Thesis, University of Reading.

Ørskov, E. R. \& Allen, D. M. (1966a). Br. F. Nutr. 20, 295.

Ørskov, E. R. \& Allen, D. M. (1966b). Br. F. Nutr. 20, 509.

Orskov, E. R. \& Allen, D. M. (I966c). Br. F. Nutr, 20, 519.

Orskov, E. R., Hovell, F. D. DeB. \& Allen, D. M. (1966). Br. F. Nutr. 20, 307.

Ørskov, E. R. \& McDonald, I. (1970). Publs Eur. Ass. Anim. Prod. no. 12, p. I 2 I.

Paladines, O. L., Reid, J. T., Bensadoun, A. \& Van Niekerk, B. D. H. (1964). F. Nutr. 82, I45.

Poole, D. A. \& Allen, D. M. (1970). Br. F. Nutr. 24, 695.

Rook, J. A. F., Balch, C. C., Campling, R. C. \& Fisher, L. J. (1963). Br. F. Nutr. I7, 399.

Skarda, J. \& Bartoš, S. (1969). Y. Endocr. 44, I15.

Sutherland, T. M. (1967). Revta cub. Cienc. agric. (Engl. edn) x, I.

Vermorel, M. (1968). Annls Biol. anim. Biochim. Biophys. 8, 453.

Wainman, F. W. \& Blaxter, K. L. (1969). Publs Eur. Ass. Anim. Prod. no. 12, p. 429.

Wainman, F. W. \& Paterson, D. (1963). 7. agric. Sci., Camb. 63, 253.

Walker, D. J. \& Forest, W. W. (I 964). Aust. F. agric. Res. I5, 299. 